\title{
Die interne rendement en meervoudige opbrengste
}

\author{
W.G. Klerck
}

Skool vir Bedryfsleiding, Universiteit van Suid-Afrika, Pretoria

\begin{abstract}
The intemal rate of relurn and multiple solutions. It is often stated that one of the problems that occurs when using the in. ternal rate of return in capital budgeting is that the method can generate multiple rates or solutions. In this article the problem of multiple rates is analysed, using the approach adopted by J.C.T. Mao in his book Quantitative Analysis of Financial Decisions. In order to implement Mao's approach a computer program was written in Apple Basic. The use of the program is illustrated with a few examples.

S. Afr. J. Bus. Mgmt. 1983, 14:96-101

Wanneer die IRR in kapitaalbegroting gebruik word, word daar soms meer as een opbrengskoers vir 'n gegewe projek verkry. Hierdie probleem ontstaan as gevolg van die foutiewe aanname wat gemaak word naamlik dat die IRR van 'n projek onafhanklik is van die koste van kapitaal.

Ten einde die probleem te oorbrug is beleggings na aanleiding van Mao geklassifiseer as suiwer of gemeng. Slegs in die geval van suiwer beleggings is die betrokke aanname geldig en kan die IRR soos gewoonlik bereken word. Vir gemengde beleggings is die IRR afhanklik van die koste van kapitaal en moet ' $n$ ander benadering gevolg word om die IRR te bereken. Die metode wat gevolg moet word is in die artikel bespreek en is ' $n$ rekenaarprogram in Apple Basic geskrywe wat die metode implementeer.
\end{abstract}

S.Air. Tydskr. Bedryfsl. 1983, 14: $96-101$

\section{Inleiding}

Die gebruik van die internerentabiliteitsmetode (IRR) ir kapitaalbegroting is algemeen bekend. Dit is ook bekenc dat een van die tekortkominge van hierdie metode die feil is dat onder sekere omstandighede dié metode meer as eer opbrengskoers vir 'n gegewe projek lewer. Weston en Brigham', Brealey en Myers ${ }^{2}$, asook Jones ${ }^{3}$ in 'n onlangse publikasie maak melding van hierdie probleem. Daar word egter nie aangetoon hoe die probleem oorbrug kan word nie. Wat oënskynlik minder bekend is, is die benadering wat $\mathrm{MaO}^{4}$ volg om dié probleem op te los. In hierdie artikel sal die benadering van Mao bespreek word en sal 'n rekenaarprogram (geskryf in Appel Basic) verskaf word wat Mao se benadering implementeer. Die gebruik van die program aan die hand van enkele voorbeelde sal ook geillustreer word.

Die IRR word gedefinieer as daardie opbrengskoers wat die huidige waarde van 'n projek gelykstel aan nul. Indien $A_{t}$ die netto kontantvloei aan die einde van jaar $t$ is, dan word die IRR ( $\left.\mathrm{r}^{*}\right)$ van die projek met ' $n$ lewensduur van $\mathrm{n}$ jaar gegee deur die uitdrukking:

$$
t=\sum_{0}^{n} \frac{A_{t}}{\left(1+r^{*}\right)^{t}}=0
$$

Indien albei kante van bogenoemde vergelyking met $\left(1+\mathrm{r}^{*}\right)^{\mathrm{n}}$ vermenigvuldig word, reduseer die vergelyking na

$$
t=\sum_{0}^{n} A_{t}\left(1+r^{*}\right)^{n-1}=0
$$

Hierdie is 'n polinoom van graad $n$ en die wyse waarop die wortel van die polinoom (die waarde van $\mathrm{r}^{*}$ ) bereken kan word, sal later in die artikel uiteengesit word.

Die tipiese belegging bestaan gewoonlik uit aanvanklike uitgawes wat aanleiding gee tot toekomstige inkomstes. Figuur 1 is ' $n$ grafiese voorstelling van ' $n$ tipiese belegging.

\section{W.G. Klerck}

Mede-Professor, Skool vir Bedryfsleiding,

Universiteit van Suid-Afrika, Posbus 392, Pretoria 0001,

Republiek van Suid-Afrika

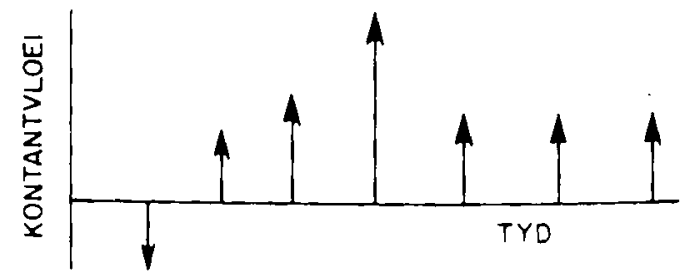

Figuur 1 Kontantvloei vir 'n tipiese belegging 
In dié tipe belegging is die aanvanklike kontantvloei $\left(\mathrm{A}_{0}\right)$ negatief en die latere kontantvloei $\left(A_{1}, A_{2}, A_{3}\right)$ positief. Vir sulke tipe beleggings (bekend as konvensionele beleggings) is daar ' $n$ unieke waarde vir $r^{*}$ (sien bv. Johnson ${ }^{3}$ ).

Beleggings met kontantstrome soos aangetoon in Figuur 2 mag egter meer as een waarde van $r^{*}$ tot gevolg hê; met ander woorde sulke beleggings kan meervoudige opbrengste lewer. Hierdie tipe beleggings staan bekend as niekonvensionele beleggings.

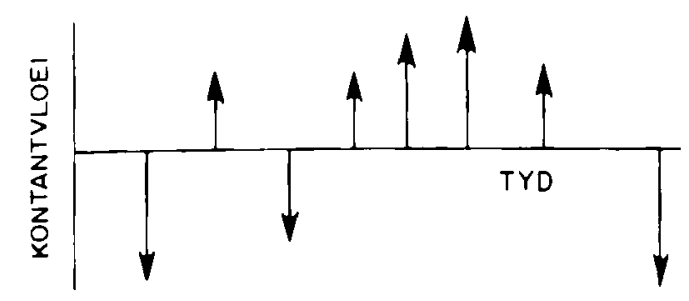

Fogur 2 Nie-konvensionele kontantstrome

In konvensionele beleggings word die berekening van die IRR nie beinvloed deur die koste van kapitaal nie; dit is onafhanklik van die koste van kapitaal en dus intern tot die projek. Vandaar die benaming interne rendement. In die geval van nie-konvensionele beleggings is die "interne rendement' nie noodwendig onafhanklik van die koste van kapitaal nie. Om hierdie aspek te verduidelik is dit nodig om die volgende konsepte eers te bespreek:

- Projekbalans van 'n belegging

- Suiwer- en gemengde beleggings

\section{Die projekbalans van 'n belegging}

Beskou ' $n$ belegging wat ' $n$ kontantstroom van $A_{t}$ aan die einde van jaar $t$ tot gevolg het. $(\mathrm{t}=0,1,2, \ldots, \mathrm{n})$. Indien die opbrengskoers $i$ is, is die waarde van die projek aan die einde van jaar

$$
\begin{array}{r}
t S_{r}(i)=A_{0}(1+i)^{t}+A_{1}(1+i)^{t-1}+\ldots+A_{t} \\
0 \leqq t \leqq n
\end{array}
$$

$S_{\text {, }}(\mathrm{i})$ staan bekend as die projekbalans van 'n belegging. Die projekbalans aan die einde van 'n projek se lewensduur word gegee deur die uitdrukking:

$S_{n}(i)=A_{0}(1+i)^{n}+A_{1}(1+i)^{n-1}+\ldots+A_{n}$

en is die toekomstige waarde van die projek. Die projekbalans kan op enige tydstip bepaal word terwyl die toekomstige waarde slegs verwys na die waarde aan die einde van 'n projek se lewensduur.

Die projekbalans van 'n belegging het 'n ekonomiese betekenis. Beskou weereens ' $n$ belegging met kontantstrome $\operatorname{van} A_{0}, A_{1}, A_{2} \ldots A_{n}$. Veronderstel $A_{0}<0$ en dat die orige $A^{\prime}$ 's positief of negatief kan wees. Behalwe wanneer $t=0$ kan die projekbalanse negatief, positief of nul wees. Indien $i$ die algehele opbrengs van die projek is, dan impliseer ' $n$ negatiewe $S_{t}(i)$ dat die opbrengs verkry tot en met tydstip $t$ minder is as die algehele opbrengs i. Die onderneming het dus tot en met tydstip $t$ nie al die kontant gebruik wat dit te wagte is nie. ' $n$ Positiewe $S_{t}(i)$ beteken dat op tydstip $t$ die opbrengs hoër is as $\mathrm{i}$ en dat die onderneming op daar- die stadium meer kontant onttrek of gebruik het as wat dit in totaal gaan ontvang. Met ander woorde in die daaropvolgende jaar $(t+1)$ het die onderneming 'n oortrokke rekening van $S_{t}(i)$ rand. Wanneer $S_{t}(i)$ gelyk is aan nul is die opbrengs ontvang op tydstip t gelykstaande aan i.

\section{Suiwer en gemengde beleggings}

' $n$ Suiwer belegging is een waarvoor die projekbalanse, bereken teen die IRR altyd nul of negatief is. Die belegging is 'suiwer' aangesien die onderneming nooit meer kontant onttrek as wat dit gaan ontvang nie. 'n Belegging is dus suiwer as $\mathrm{S}_{\mathrm{t}}\left(\mathrm{r}^{*}\right) \leqq 0$ vir $\mathrm{t}=0,1,2, \ldots, \mathrm{n}-1$, waar $\mathrm{r}^{*}$ die interne rendement van die projek is.

'n Gemengde belegging daarenteen is een waarvoor $S_{1}\left(r^{*}\right)$ $>0$ vir sommige waardes van $t$ en $S_{t}\left(r^{*}\right)<0$ vir die orige waardes van $t$.

Dié onderskeid is gemaak om aan te toon dat slegs in die geval van suiwer beleggings die opbrengskoers onafhanklik is van die koste van kapitaal. Met ander woorde vir suiwer beleggings is die opbrengskoers intern tot die projek.

Die opbrengskoers van gemengde beleggings daarenteen is nie onafhanklik van die koste van kapitaal nie. Op sekere tydstippe (wanneer $S_{1}\left(r^{*}\right)>0$ ) het die onderneming ' $n$ oortrokke rekening teen die projek en sal die opbrengskoers gevolglik beinvloed word deur die koste van kapitaal. In so 'n geval sal 'n ander benadering gevolg moet word om die IRR te bereken. Hierdia aspek kan met behulp van 'n voorbeeld geillustreer word.

Veronderstel die kontantvloei van ' $n$ belegging is as volg:

$A_{0}=-10$

$A_{1}=40$

$A_{2}=-40$.

Die interne rendement $r^{*}$ kan verkry word deur die vergelyking

$-10+\frac{40}{1+r^{*}}-\frac{40}{\left(1+r^{*}\right)^{2}}=0$

op te los. Die waarde van $r^{*}$ is $100 \%$ en indien die koste van kapitaal $10 \%$ is behoort die projek aanvaar te word. Die netto huidige waarde van die belegging teen 'n verdiskonteringskoers van $10 \%$ is egter $-6,70$.

Indien die belegging dus aanvaar word sal dit die markwaarde van die onderneming verminder.

Hierdie teenstrydigheid kan verklaar word deur daarop te let dat die belegging ' $n$ gemengde belegging is. Die projekbalanse van die belegging is:

$\mathrm{S}_{0}(100 \%)=-10$

$S_{1}(100 \%)=20$

en gevolglik is dit 'n gemengde belegging. In 'n gemengde belegging is die 'interne' rendement nie onafhanklik van die koste van kapitaal nie en is bogenoemde opbrengskoers van $100 \%$ foutief. Indien die koste van kapitaal van $10 \%$ in ag geneem word is die 'interne' rendement $-63,6$. Dié wyse waarop hierdie opbrengskoers bereken is sal later aangetoon word.

Die identifisering van suiwer en gemengde beleggings

Bogenoemde klassifikasie van projekte gaan van die veronderstelling uit dat die IRR bekend is; met ander woorde indien die IRR bekend is kan 'n belegging as suiwer 
of gemeng geklassifiseer word. A priori is die IRR nie bekend nie en moet ' $n$ ander metode gevolg word om beleggings as suiwer of gemeng te klassifiseer.

Indien $\mathrm{A}_{0}<0$ kan daar gesorg word dat enige belegging aan die vereiste $S_{t}(i) \leqq 0$ vir $t=0,1,2 \ldots, n-1$ voldoen. Dit word gedoen deur die verdiskonteringskoers i te verhoog totdat $\mathrm{S}_{\mathrm{t}}(\mathrm{i}) \leqq 0$ vir $\mathrm{t}=0,1,2, \ldots, \mathrm{n}-1$. Veronderstel hierdie verdiskonteringskoers is $\mathbf{r}$ min. Dit is belangrik om daarop te let dat $\mathrm{r}$ min die kleinste verdiskonteringskoers is waarvoor $S_{t}(i) \leqq 0$ vir $t=0,1,2, \ldots, n-1$. In so ' $n$ geval is $S_{n}(r \mathrm{~min})$ of negatief of nul of positief. Indien $S_{n^{-}}$ ( $r$ min) $\geqq 0$ bestaan daar ' $n$ koers $r^{*}$ wat groter is as $r$ min en waarvoor $S_{n}\left(r^{*}\right)=0$. Wanneer die verdiskonteringskoers verhoog word, word die projekbalanse kleiner. Aangesien $r^{*}>r$ min en aangesien $S_{t}(r$ min $) \leqq 0$ vir $t=0,1,2, \ldots$, $\mathrm{n}-1$ moet $\mathrm{S}_{\mathrm{t}}\left(\mathrm{r}^{*}\right) \leqq 0$ vir $\mathrm{t}=0,1,2, \ldots, \mathrm{n}-1$. Wanneer $S_{n}(r$ min $) \geqq 0$ het ons dus te doen met 'n suiwer belegging.

As $S_{n}(r$ min $)<0$ bestaan daar ' $n$ koers $r^{*}<r$ min wat $S_{n}\left(r^{*}\right)=0$ stel. Aangesien rmin die kleinste waarde is waarvoor die balanse almal negatief is, volg dit dat wanneer die balanse teen $r^{*}$ verdiskonteer word almal nie negatief kan wees nie. Met ander woorde wanneer $S_{n}(r$ min $)<0$ is die belegging 'n gemengde een.

Die waarde van $r$ min word met behulp van 'n iteratiewe proses, geïmplementeer op 'n rekenaar, bepaal.

\section{Die klassifikasie van projekte}

Tot dusver is beleggings eers geklassifiseer as konvensioneel of nie-konvensioneel. Daarna is beleggings ook geklassifiseer as suiwer of gemeng. Daar bestaan wel 'n verband tussen hierdie verskillende klassifikasies. Die verband is die volgende:

- 'n konvensionele belegging is altyd ook 'n suiwer belegging.

- 'n suiwer belegging is nie noodwendig konvensioneel nie.

- 'n gemengde belegging is altyd ook 'n nie-konvensionele belegging.

'n Konvensionele belegging ook 'n suiwer belegging

Vir konvensionele beleggings is $\mathbf{A}_{0}<0(\mathrm{t}=1,2, \ldots, \mathrm{n})$. Indien $r^{*}$ die IRR is, is $S_{n}\left(r^{*}\right)=0$. Veronderstel $\operatorname{St}\left(r^{*}\right)>$ 0 vir een of ander waarde van t tussen 1 en $n-1$. St $+1\left(r^{*}\right)$ kan in terme van $s t\left(r^{*}\right)$ uitgedruk word:

$$
\begin{aligned}
S t+1\left(r^{*}\right)= & A_{0}\left(1+r^{*}\right)^{t+1}+A_{1}\left(1+r^{*}\right)^{t} \\
& +\ldots+A_{t+1} \\
= & \left(1+r^{*}\right) / A_{0}\left(1+r^{*}\right)^{t}+A_{1}\left(1+r^{*}\right)^{t-1} \\
& +\ldots+A_{t}+A_{t+1} \\
= & \left(1+r^{*}\right) S_{t}\left(r^{*}\right)+A_{t+1}
\end{aligned}
$$

Aangesien $r^{*}>0$ en $A_{t} \geqq 0$ vir $t=1,2, \ldots, n$ sal $S_{t+1}$ $\left(r^{*}\right)>0$ as $S_{t}\left(r^{*}\right)>0 . S_{t+1}\left(r^{*}\right)>0$ impliseer dan ook dat $S_{t+2}\left(r^{*}\right)>0$ en uiteindelik ook $S_{n}\left(r^{*}\right)$. Dit weerspreek die feit dat $S_{n}\left(r^{*}\right)=0$. Geeneen van die balanse van die belegging kan dus positief wees nie en gevolglik is ' $n$ konvensionele belegging altyd 'n suiwer belegging.

\section{Nie-konvensionele suiwer beleggings}

Dat 'n suiwer belegging nie noodwendig 'n konvensionele belegging is nie kan uit die volgende voorbeeld waargeneem word:

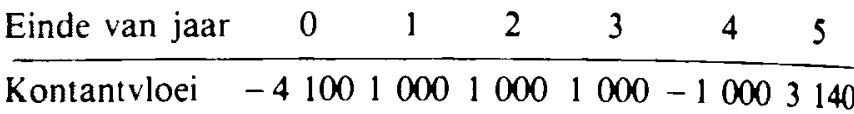

Die negatiewe kontantvloei in jaar 4 toon dat die belegging nie-konvensioneel is. Berekenings toon ook dat die IRR van die belegging $7 \%$ is. Teen 'n verdiskonteringskoers van $7 \%$ is die balanse van die belegging:

$\begin{array}{ll}S_{0}(7 \%)=-4100 & S_{3}(7 \%)=-1808 \\ S_{1}(7 \%)=-3387 & S_{4}(7 \%)=-2935 \\ S_{2}(7 \%)=-2624 & S_{5}(7 \%)=0\end{array}$

Aangesien $\mathrm{S}_{\mathrm{t}}(7 \%) \leqq 0$ vir $\mathrm{t}=0,1,2,3,4$ is dié niekonvensionele belegging ook 'n suiwer belegging.

\section{'n Gemengde belegging is ook 'n nie-konvensionele belegging}

Om aan te toon dat ' $n$ gemengde belegging noodwendig ook 'n nie-konvensionele belegging moet wees is dit slegs nodig om die balanse van die belegging as volg uit te druk:

$$
\begin{aligned}
S_{0}\left(r^{*}\right) & =A_{0} \quad A_{0}<0 \\
S_{1}\left(r^{*}\right) & =A_{0}\left(1+r^{*}\right)+A_{1} \\
& =S_{0}\left(1+r^{*}\right)+A_{1} \\
S_{2}\left(r^{*}\right) & =S_{1}\left(1+r^{*}\right)+A_{2} \\
S_{n}\left(r^{*}\right) & =S_{n-1}\left(1+r^{*}\right)+A_{n}
\end{aligned}
$$

'n Gemengde belegging is een waarvoor $\mathrm{S}_{\mathrm{t}}\left(\mathrm{r}^{*}\right)<0$ vir sommige waardes van $t$ en $\mathrm{S}_{1}\left(\mathrm{r}^{*}\right)>0$ vir die ander waardes van t. Indien byvoorbeeld $S_{t}\left(r^{*}\right)>0$ kan een van die ander balanse $S_{k}\left(r^{*}\right)(K>t)$. slegs negatief wees as die waarde van een van die Ai's negatief is. Indien $A_{i}$ negatief is, is die belegging nie-konvensioneel. 'n Gemengde belegging is dus altyd 'n nie-konvensionele belegging.

Die verskillende klassifikasies van die beleggings reduseer nou tot die volgende:

- Konvensionele suiwer beleggings;

- Nie-konvensionele suiwer beleggings;

- Nie-konvensionele gemengde beleggings.

Eersgenoemde twee tipe beleggings se IRR is onafhanklik van die koste van kapitaal terwyl dit nie geld vir die laasgenoemde tipe belegging nie. Die benaming IRR behoort dus nie gebruik te word vir nie-konvensionele gemengde beleggings nie aangesien die opbrengskoers nie intern tot die belegging is nie; dit is afhanklik van die koste van kapitaal. Ter wille van die bestaande gebruik sal die benaming interne rendement egter nog steeds gebruik word.

\section{Die bepaling van die interne rendement vir suiwer beleggings}

Die interne rendement vir 'n suiwer belegging word gevind deur daardie waarde $r$ (noem dit $r^{*}$ ) te bepaal wat die uitdrukking

$S_{n}(r)=A_{0}(1+r)^{n}+A_{1}(1+r)^{n-1}+\ldots+A_{n}$

gelyk aan nul stel. 'n Metode wat dikwels gevolg word is om ' $n$ reeks waardes $r_{0}, r_{1}, r_{2} \ldots$, te genereer wat uiteindelik konvergeer tot $r^{*}$. Hierdie reeks waardes word bepaal met behulp van die uitdrukking: 
$r_{i+1}=r_{i}-\frac{S_{n}\left(r_{i}\right)}{H\left(r_{i}\right)}$

waar $H\left(r_{i}\right)$ die helling van 'n geskikte lyn is. Die korrekte waarde van $H\left(r_{i}\right)$ is die helling van die lyn wat die punte $\left(r_{i}, S_{n}\left(r_{i}\right)\right)$ en $\left(r^{*}, S_{n}\left(r^{*}\right)\right)$ verbind.

$$
\text { As } \begin{aligned}
H\left(r_{i}\right) & =\frac{S_{n}\left(r_{i}\right)-S_{n}\left(r^{*}\right)}{r_{i}-r^{*}} \\
& =\frac{S_{n}\left(r_{i}\right)}{r_{i}-r^{*}}
\end{aligned}
$$

dan is

$$
\begin{aligned}
r_{i+1} & =r_{i}-\frac{S_{n}\left(r_{i}\right)}{S_{n}\left(r_{i}\right)}\left(r_{i}-r^{*}\right) \\
& =r^{*}
\end{aligned}
$$

Aangesien die waarde van $\mathrm{r}^{*}$ onbekend is, is dit nie moontlik om die korrekte helling te bepaal nie. As 'n benadering word die afgeleide van $S_{n}\left(r_{i}\right)$ gebruik (Sien byvoorbeeld Hildebrand ${ }^{5}$ ).

Die uitdrukking gebruik om $\mathrm{r}^{*}$ te bepaal reduseer dan na

$$
r_{i, l}=r_{i}-\frac{S_{n}\left(r_{i}\right)}{S_{n}^{1}\left(r_{i}\right)} \quad i=0,1,2, \ldots,
$$

Om die metode te genereer word 'n willekeurige waarde vir $r_{0}$ (gewoonlik tussen 0 en 1) gekies. Die soekproses (om r* te vind) word beeindig wanneer $S_{n}\left(r_{i}\right)$ gelyk is aan nul. Dié metode staan bekend as die benadering van NewtonRaphson (sien byvoorbeeld Hildebrand ${ }^{5}$ ). 'n Eenvoudige voorbeeld sal gebruik word om die metode te illustreer: Gegee die volgende kontantstrome:

$\begin{array}{cc}\text { Jaar } & \text { Kontantstroom } \\ 0 & -1000 \\ 1 & 452 \\ 2 & 500 \\ 3 & 278\end{array}$

Indien $r_{0}=0,3$ gestel word, is die waardes van $S_{n}\left(r_{0}\right)$ en $S_{n}^{1}\left(r_{0}\right)-505,1$ en $-3394,8$ onderskeidelik. Aangesien $S_{n}\left(r_{0}\right)$ ongelyk is aan nul moet die volgende waarde van $r$, naamlik $r_{1}$, bereken word:

$$
\begin{aligned}
r_{1} & =0,3-(\cdots 505,1) /(-3394,8) \\
& =0,151
\end{aligned}
$$

Hierdie proses word voortgesit totdat $S_{n}(r)$ gelyk is aan nul. $\mathrm{Vir}$ die genoemde voorbeeld is die stappe:

\begin{tabular}{clcc} 
Iterasie & \multicolumn{1}{c}{ r } & \multicolumn{1}{c}{$\mathrm{S}_{\mathbf{n}}$} & $\mathrm{S}_{\mathbf{n}}^{1}$ \\
\hline 1 & 0,3 & $-505,1$ & $-3394,8$ \\
2 & 0,151 & $-73,0$ & $-2435,1$ \\
3 & 0,121 & $-2,7$ & $-2257,9$ \\
4 & 0,120 & 0 &
\end{tabular}

Die IRR van bogenoemde voorbeeld is dus $12 \%$.

\section{Die bepaling van die interne rendement vir gemengde beleggings}

Gemengde beleggings het die eienskap dat gedurende sekere periodes die onderneming minder fondse onttrek het aan die projek as wat dit in totaal gaan ontvang. Gedurende ander periodes het dit weer meer fondse onttrek. Wanneer minder fondse onttrek is (projekbalans van die belegging is negatief) moet die balanse van die projek verdiskonteer word teen die interne rendement. Wanneer meer fondse onttrek is (projekbalans van die belegging is positief) moet die balanse van die projek verdiskonteer word teen die koste van kapitaal.

Omdat die projekbalanse van die belegging verdiskonteer word teen $r$ en $K$, is die toekomstige waarde $S_{n}(r, K)$ van die projek 'n funksie van $r$ en $K$. Aangesien die projek aan die einde van jaar $n$ eindig, is $S_{n}(r, K)=0$. Met behulp van hierdie vergelyking word die waarde van $r$ vasgestel. Die stappe benodig om die waarde van $r$ te bepaal kan as volg saamgevat word:

- Bereken $S_{\mathrm{r}}(r, K)$ volgens bogenoemde prosedure naamlik

$$
\begin{aligned}
S_{0}(r, K)= & A_{0} \\
S_{1}(r, K)= & S_{0}(1+r)+A_{1} \text { as } S_{0}<0 \text { (verdiskonteer } \\
& \text { teen } r) \\
= & S_{0}(1+K)+A_{1} \text { as } S_{0}>0 \text { (verdiskonteer } \\
& \text { teen } K) \\
S_{2}(r, K)= & S_{1}(1+r)+A_{2} \text { as } S_{1}<0 \\
= & S_{1}(1+K)+A_{2} \text { as } S_{1}>0 \\
S_{n}(r, K)= & S_{n-1}(1+r)+A_{n} \text { as } S_{n}<0 \\
= & S_{n-1}(1+K)+A_{n} \text { as } S_{n}>0
\end{aligned}
$$

- Bepaal die waarde van $r$ wat $S_{n}(r, K)=0$ stel.

'n Iteratiewe soekproses word gebruik om $r$ te bepaal. Met behulp van die rekenaar word verskillende waardes van $r$ geselekteer en daardie waarde van $r$ wat vir' $n$ gegewe $\mathbf{K}$ $S_{n}(r, K)=0$ stel, is dan die 'interne rendement' van dic projek.

Die volgende voorbeeld ('n gemengde belegging) sal gebruik word om bogenoemde metode te illustrcer:

\begin{tabular}{llll} 
Jaar & 0 & 1 & 2 \\
\hline Kontantvloei & -1600 & 10000 & -10000
\end{tabular}

In die voorbeeld is die koste van kapitaal $\mathrm{K} 10 \%$. Die eerste stap in die berekening van $r$ is om ' $n$ waarde van $r$ te selekteer en dan die balanse van die projek volgens bogenoemde reëls te bereken. ' $n$ Waarde gelykstaande aan nul word as 'n eerste waarde vir $r$ geselekteer. Die balanse van die projek is:

$$
\begin{aligned}
S_{0}(r, K) & =-1600 \\
S_{1}(r, K)= & -1600(1+r)+10000 \\
= & -1600-1600 r+10000 \\
= & 8400 \quad(r=0) \\
& S_{1}(r, K) \geqq 0 \\
\therefore S_{2}(r, K)= & 8400(1+K)-10000 \\
= & 9240-10000 \\
= & -760 .
\end{aligned}
$$

Omdat $\mathrm{S}_{2}(\mathrm{r}, \mathrm{K})$ nie gelyk is aan nul nie en boonop ook negatief is, word die geselekteerde waarde van $r$ verminder. Die keuse van die vermindering (willekeurig) is in die voorbeeld op $0,002(0,2 \%)$ gestel. Die proses word nou herhaal totdat $S_{2}(r, K)$ gelyk is aan nul. In die besondere geval sal 'n waarde van $r=-0,432 S_{2}(r, K)$ gelyk aan nul stel. Die 'interne rendement' van die belegging is dus $-43,2 \%$ en behoort die projek nie aanvaar te word nie. 
Wanneer die tradisionele benadering gevolg word om die interne rendement $r^{*}$ van die belegging te bepaal word daar gevind dat $\mathrm{r}^{*} 25 \%$ en $400 \%$ is. Die projek behoort dus aanvaar te word as die koste van kapitaal $10 \%$ is. Hierdie teenstrydigheid ontstaan as gevolg van die feit dat die tradisionele benadering aanvaar dat die interne rendement onafhanklik van die koste van kapitaal is.

\section{'n Rekenaarprogram om die IRR van 'n belegging te bereken}

In dié gedeelte word 'n rekenaarprogram beskrywe wat die IRR van 'n projek bereken. Die program is geskryf in Apple Basic en word in Bylae 1 getoon. Die stappe wat die program uitvoer kan as volg opgesom word:

(a) Voer die data in.

(b) Bepaal die aard van die belegging, dit wil sê konvensioneel of nie-konvensioneel

- Indien konvensioneel bepaal die IRR met behulp van die Newton-Raphson iteratiewe proses. Die probleem is afgehandel en die program eindig dus hier.

- Indien nie-konvensioneel vind $r$ min en gaan na stap 3.

(c) Bepaal die waarde van $S_{n}(r$ min)

- Indien $S_{n}(r$ min $)>0$ is die belegging ' $n$ niekonvensionele suiwer belegging en word die IRR met behulp van die Newton-Raphson metode bepaal.

- Indien $S_{n}(r \mathrm{~min})<0$ is die belegging ' $n$ niekonvensionele gemengde belegging en is die IRR afhanklik van die koste van kapitaal. Die IRR word bereken vir 'n gegewe waarde van $K$. Die waarde van I wat $S_{n}(r, K)=0$, stel is die 'interne rendement' van die projek.

\section{Voorbeelde}

Die gebruik van die rekenaarprogram sal aan die hand van enkele voorbeelde geillustreer word:

\section{Eerste voorbeeld}

Einde van Jaar

Kontantvloei
-1000
500
400
300
100

Dit is ' $n$ konvensionele belegging en die IRR $=14,4 \%$

\section{Tweede voorbeeld}

$\begin{array}{cc}\text { Einde van Jaar } & \text { Kontantvloei } \\ 0 & -1600 \\ 1 & 10000 \\ 2 & -10000\end{array}$

Hierdie is die bekende voorbeeld van Lorie en Savage. ${ }^{6}$ As die tradisionele benadering gevolg word om die IRR te bereken word twee opbrengskoerse verkry naamlik $25 \%$ en $400 \%$.

Dit is egter 'n nie-konvensionele gemengde belegging aangesien $S_{2}(r \mathrm{~min})$ negatief is (Die waarde van $\mathrm{r}$ min is $525 \%$ ). Wanneer die koste van kapitaal $25 \%$ is, is die IRR ook $25 \%$. Met behulp van die rekenaar kan vir elke gegewe waarde van $K$ ' $n$ IRR bereken word:

$\begin{array}{lc}K & I R R \\ 10 \% & -43,2 \% \\ 20 & 4,1 \\ 25 & 25,0 \\ 30 & 44,2 \\ 50 & 108,3 \\ 100 & 212,5 \\ 400 & 400 \\ 500 & 420,8\end{array}$

Wanneer die koste van kapitaal K tussen $25 \%$ en $400 \%$ is, is die IRR groter as $K$ en kan die projek aanvaar word. Wanneer $\mathrm{K}$ kleiner as $25 \%$ of groter as $400 \%$ is, is die IRR kleiner as $\mathrm{K}$ en moet die projek verwerp word.

\section{Samevatting}

Wanneer die IRR in kapitaalbegroting gebruik word, word daar soms meer as een opbrengskoers vir 'n gegewe projek verkry. Hierdie probleem ontstaan as gevolg van die foutiewe aanname wat gemaak word naamlik dat die IRR van 'n projek onafhanklik is van die koste van kapitaal.

Ten einde die probleem te oorbrug is beleggings na aanleiding van Mao geklassifiseer as suiwer of gemeng. Slegs in die geval van suiwer beleggings is die betrokke aanname geldig en kan die IRR soos gewoonlik bereken word. Vir gemengde beleggings is die IRR afhanklik van die koste van kapitaal en moet ' $n$ ander benadering gevolg word om die IRR te bereken. Die metode wat gevolg moet word is in die artikel bespreek en is ' $n$ rekenaarprogram in Apple Basic geskrywe wat die metode implementeer.

\section{Summary}

It is often stated that one of the problems that can occur when using the internal rate of return in capital budgeting is that the method can generate multiple rates or solutions. In this article the problem of multiple rates is analysed, using the approach adopted by J.C.T. Mao in his book Quantitative Analysis of Financial Decisions. Investments are classified as either simple or nonsimple. A simple investment is one whose net cash flow takes the pattern of an initial outlay followed by cash receipts alone. A nonsimple investment on the other hand, is one whose net cash outflows are not restricted to the initial period, but are interposed with net cash inflows throughout the life of the project. Investments are also classified as being either pure or mixed. An investment is pure if the firm does not overdraw on its return at any point in time and hence is not indebted to the project. A mixed investment on the other hand is any investment that is not pure. The article indicates that all simple investments are pure and that nonsimple investments may be either mixed or pure. All pure investments (simple or nonsimple) have only one internal rate of return and the return is independent of the cost of capital. Nonsimple mixed investments can generate multiple rates of return and the article discusses how this problem can be solved.

In order to implement the proposed solution a computer program was written in Apple Basic. The use of the program is illustrated with a few examples. 


\section{Vermsings}

1. Weston, J.F. \& Brigham. E.F. 1978. Manugerial Finunce: Hinsdale, llinois: The Dryden Press.

2. Brealey, R. \& Myers. S. 1981 . Principles of Corporate Finance. Johannesburg: McGraw-Hill Bwok.

3. Jones, B.W. Company. 1982. Inflation in Engineering. Economi Analysis, 1982. Vew York: John $W$ ilen \& Sons.

4. Mao. J.C.T. 1969. Quantitative Analysis of Financial Decisions. London: Collier-Mac:Millan Lid.

5. Hildebrand, F.B. Introduction to Numerical Analysis, 1956. New York: McGraw-Hill.

6. Loric, J.H. \& Sarage. L.J. Three Problems in Rationing Capital. J. Bus. 28 (OC. 1955).

\section{Byoe 1}

\section{Beaic-Program - Inteme Rendement}

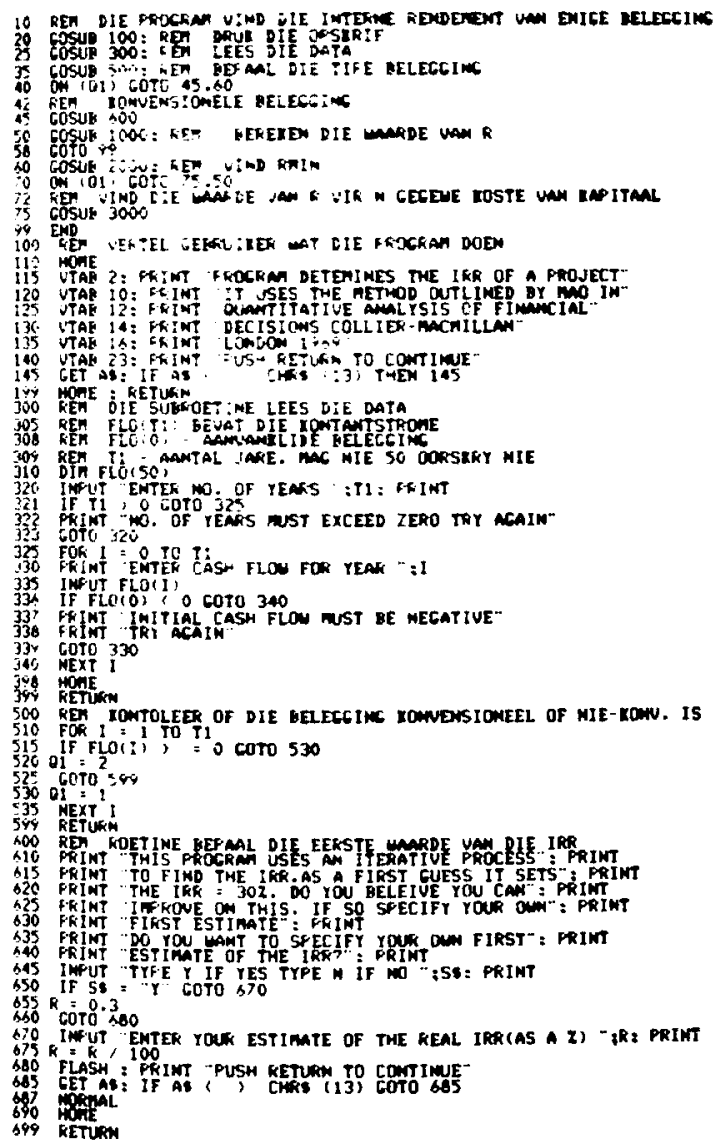

Byon 1 - vang

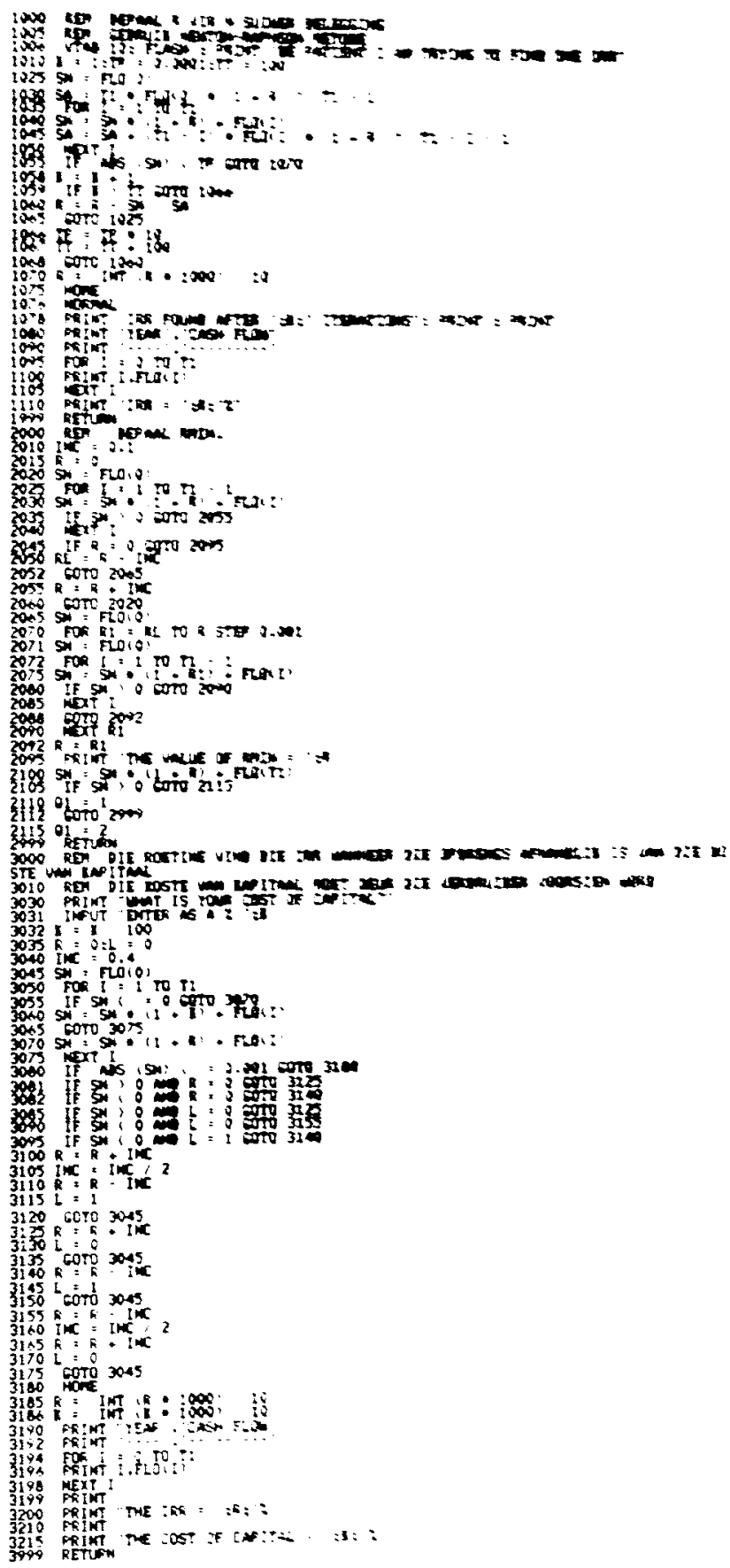

